\title{
Absenteeism of Employees in a BPO Company
}

\author{
S. Sangeetha, G. Sundharavadivel
}

\begin{abstract}
The concept of absenteeism has been explained so far in various ways. According to one line of thought, absenteeism is due to a lack of "commitment" on the side of the workforce. It is related to new values and norms, which are developing among the employees, as a result of technological developments. Work and leisure are now cherished by the employees, which they want to enjoy along with the monetary benefits from the services. American authors hold the view that absenteeism is due to the "internal administration of an organization". According to them, "the work milieu is very important since a large part of the worker's daily life is spent there". The atmosphere in the workplace, therefore, affects the attitude towards the work, and either persuades the workers to attend regularly or keeps them away. Irritating uncertainty, irregularity, and confusion in the workplace are likely to be important causes of absenteeism. The attitude and practice of the management also contribute to absenteeism. A traditional management treats employees as hirelings, while an enlightened management treats them as human beings. This difference in behavior leads, in the former situation, to high absenteeism, and in the latter situation to a close affinity with the organization and resulted in lower absenteeism.

This paper outlines the various aspects and impacts of absenteeism in a BPO industry. Sample sizes of 75 participants were taken in order to conduct research and random sampling technique was used in order to conduct the survey. The data was collected by interviewing the respondents with the help of a structured questionnaire.
\end{abstract}

Keywords : About four key words or phrases in alphabetical order, separated by commas.

\section{INTRODUCTION} is inversely related to industrial development".

In a BPO sector, absenteeism is mainly affected by factors like relationship with superiors and co- workers, family size, economic causes, social causes, religious ceremonies, unsatisfactory housing conditions, unhealthy working condition, inadequate leave facilities, absence of adequate welfare facilities, Indebtedness and Alcoholism.

Absenteeism signifies the absence of an employee from work when there is scheduled to be at work; it is unauthorized, unexplained, avoidable, and willful absence from work. Any employee may stay away from work if he has taken leave, to which he is entitled, or on the ground of sickness or some accident, or without any previous sanction

Revised Manuscript Received on December 05, 2019.

* Correspondence Author

S. Sangeetha*, Research Scholar, Department of Adult \& Continuing Education, School of Social Sciences, University of Madras, Chennai, India.

Dr. G. Sundharavadivel, Professor, Department of Adult \& Continuing Education, School of Social Sciences, University of Madras, Chennai, India.
According to Clark Kerr and his associates "absenteeism

of leave. Thus, absence may be authorized or unauthorized, willful or caused by circumstances beyond one's control.

\section{OBJECTIVE OF THE STUDY}

\section{Primary Objective:}

- To study and understand the impact of absenteeism in a BPO Company

\section{Secondary Objectives:}

- To study the rate of absenteeism for all Level of employees

- To study the reason for absenteeism

- To study the cost of absenteeism in BPO business

- To study the association between demographic and other organizational factors

- To suggest measures to reduce absenteeism.

\section{ABSENTEEISM}

- The absenteeism in industries has been studied so far in different parts of the country, and few observations have been made out.

- The rate of absenteeism on salary day is the lowest and it increases considerably on the days following the payment of salary and bonus.

- The level of absenteeism is comparatively high immediately after the date of salary, when employees either feel like having a good time, or in some other cases return home to their village to make purchases for the family and to meet them.

- The incidence of absenteeism, both before and after a holiday, has also been found to be higher than that on normal days.

- Absenteeism is generally high among employees below 25 years and above 40 years of age.

- The younger employees are not regular and punctual. Apparently because of the employment of a large number of newcomers among the younger age groups; while the older people are not able to withstand the vigorous nature of the work

- The percentage of absenteeism is generally higher in unorganized companies than in organized companies.

- The high percentage of absenteeism in unorganized sector is due to the engagement of labor in the fields, holidays, functions like marriages and festivals, which together are estimated to account for about 75 percent of the cases of withdrawals drunkenness, relaxation or sickness.

- Absenteeism in India is seasonal in character and It is the highest during March - April - May due to summer vacation. 


\section{FACTORS AFFECTING ABSENTEEISM}

There are various factors that impact absenteeism in industries and below are the highlighted ones for detailed review.

\section{Relationship with Supervisors}

Relationship of the employees with their direct supervisor is known to have an impact on the frequency of absent to work. An employee who is having a poor relationship with his/her superiors is more likely to have increased number of absence to work.

\section{Relationship with Co-Workers}

Employees who are not having a good relationship with co-workers would end up with absenteeism. Hence, a poor relationship with co-workers results in increased absenteeism.

\section{Economic Causes}

Studies have shown that the employees are entitled to sick leave with pay. So, they tend to avail the privileges of sick leave by reporting to work as sick.

\section{Social Cause}

Employees are tend to fulfill the social and family obligations like wedding, festivals, repair \& maintenance in their house and to go back to their villages during saving and harvest seasons.

\section{Family Size}

Absenteeism has been observed to be higher among employees from large families. The factor in the Indian context includes the following.

- Low salary, which forces an employees to seek additional part time job to meet family requirement.

- Lack of welfare facilities at work place, lack of adequate leave facilities in the organization to involve themselves in social and religious obligation.

- Imbalance between family conflicts and job responsibilities.

\section{Non-Occupational Causes}

Due to poor nutrient disorder, bad health condition or sickness, the effect of absenteeism is alarming. This resulting in loss of production, increased labor costs and additional cost to the company due to overtime double pay for extending the work hours. Absenteeism thus proves expensive to the organization.

\section{Social and Religious Ceremonies}

Social observances direct employees from work to social actions like Political activities, Water Reservoir cleaning, and Religious ceremonies like Temple festivals, makes employees to move from the work area.

\section{Unsatisfactory Housing Conditions}

The employees who come to work from other Town or Villages are forced to stay away from family in Hostels or Mansions. The facilities in these places are not good in conditions in terms of cleanliness, the quality of food provided in hostel, too many people staying in one single room, all these factors affecting the health of the employees.
Due to these, they tend to go back to their home town often and these results in absenteeism to work.

\section{Unhealthy Working Conditions}

Irritating and intolerable working condition exist in factories, heat and moisture, noise and vibrations, poor lighting conditions, dust and overcrowding affect the employees' health causing them to remain absent for work.

\section{Absence of Adequate Welfare Facilities}

Absenteeism is also occurring due to inadequate welfare facilities like cleanliness of work area, sanitation and bathing facilities, first-aid, drinking water, canteen and rest rooms. If these are not there or not in good condition, then employee gets fed up and remain absent to work frequently.

\section{Alcoholism}

The habit of alcoholism among employees is a significant cause of absenteeism, which is high in the first week of each month, when they receive the salary.

\section{Indebtedness}

Employees also suffer a high degree of indebtedness and hence they absent themselves to escape from the money lenders. As a result, absenteeism is high.

\section{Inadequate Leave Facilities}

When there is a negligence to provide adequate leave facilities force the employees to fall back on E.S.I or sick leave. Supervisor with work oriented rather than people oriented approach are also a factor which force the employees to absent themselves on an E.S.I or sick leave.

\section{Marital Status}

Married employees are known to have lower rates of absenteeism due to greater sense of responsibility on the home front.

\section{Number of Children}

Number of children an employee has is positively related with absent to work especially among females. Young mothers are still the prime responsibility for the children and they stay home to deal with sickness of family members.

\section{RESEARCH METHODOLOGY}

This is an organized, systematic approach to be the formulation, implementation and control of research work. It may also be understood as a science to expose and analyze the facts related to particular aspect. So this is an essential step in conducting a research and it is the master plan and blue print of the entire study.

\section{Sources of Data}

- Primary Data: The primary data are collected through questionnaire. It consist of 21 questions with three points scaling, which includes the factors such as demographic factors, workplace factors, social cultural factors, internal factors and other factors. 
- Secondary Data: Data that are collected from primary data i.e., they are already available. This is also been collected from company records such as Attendance, LOP list and Payroll book

\section{Samples}

Samples are the representative of the population and the study has been done with the sample of subjects, rather than the full population. However, the safest way to ensure the research with "Random Sampling Method" for a better result.

\section{Method of Sampling Used: Random Sampling Method}

In the random sampling method, the sample of employees for survey has been selected randomly at different level of work position to avoid any bias in the research work.

\section{Sample Size}

The sample size taken is 75 employees from various departments, who are working in different designation between Level-2 and Level-4 in the BPO Industry.

\section{Data Collection}

\section{Survey-Questionnaire:-}

Awareness on impact of absenteeism, Absence to work on account of Festival, Absence due to Social \& Political activity, Absence to work due to Family problem, Relationship with Supervisors, Relationship with Co-Workers, Phase of Leave Utilization, Frequency of taking leave, Planning of Leave in Advance and Awareness on leave eligibility,

\section{DATA ANALYSIS AND INTERPRETATION}

\section{A. Preferable shift time to work in BPO industry:}

- $63 \%$ of employees have shown interest to work in

- $32 \%$ of employees have shown interest to work in other shift hour.

- $5 \%$ of employees have shown interest to work in Night shift hour.

\section{B. Satisfaction with nature of job}

- $36 \%$ of employees have responded that they are very satisfied with nature of job.

- $62 \%$ of employees have responsed that they are satisfied with nature of job.

- $2 \%$ of employees have responsed that they are not satisfied with nature of job.

\section{Awareness on impact of absenteeism in production}

- $24 \%$ of employees have responded, they are very much aware on the impact of absenteeism.

- $\quad 53 \%$ of employees have responsed, they are little aware on the impact of absenteeism.

- $\quad 33 \%$ of employees have responsed, they are not aware on the impact of absenteeism.

\section{Absent to work on account of festival}

- $\quad 9 \%$ of employees have responded, they often take leave on account of festival.

- $81 \%$ of employees have responsed, they sometimes take General shift hour.

leave on account of festival.

- $10 \%$ of employees have responsed, they never take leave on account of festival.

\section{E. Absent to work due to social \& political activities}

- $1 \%$ of employees have responded, they often take leave due Social \& Political activities.

- $12 \%$ of employees have responsed, they sometimes take leave due Social \& Political activities.

- $\quad 87 \%$ of employees have responsed, they never take leave due Social \& Political activities.

\section{F. Absent to work due to problem in family}

- $6 \%$ of employees have responded, they often take leave due to problem in family.

- $58 \%$ of employees have responsed, they sometimes take leave due to problem in family.

- $46 \%$ of employees have responsed, they never take leave due to problem in family.

\section{G. Relationship with supervisor}

- $54 \%$ of employees have responded, they have good relationship with their supervisor.

- $\quad 42 \%$ of employees have responsed, they have neither good nor bad relationship with their supervisor.

- $\quad 4 \%$ of employees have responsed, they are not having good relationship with their supervisor.

\section{H. Relationship with co-workers}

- $81 \%$ of employees have responded, they have good relationship with their Co-workers.

- $17 \%$ of employees have responsed, they have neither good nor bad relationship with their Co-workers.

- $2 \%$ of employees have responsed, they are not having good relationship with their Co-workers.

\section{Phase of leave utilization}

- $15 \%$ of employees have responded, they take leave in the beginning of the month.

- $51 \%$ of employees have responsed, they take leave in the middle of the month.

- $34 \%$ of employees have responsed, they take leave in the end of the month.

\section{J. Frequency of taking leave}

- $\quad 9 \%$ of employees have responded, they often take leave from work.

- $\quad 73 \%$ of employees have responsed, they sometime take leave from work.

- $18 \%$ of employees have responsed, they seldom take leave from work.

\section{K. Planning of leave in advance:}

- $18 \%$ of employees have responded, they often plan leave in advance.

- $\quad 72 \%$ of employees have responsed, they they sometime plan leave in advance. 
- $10 \%$ of employees have responsed, they never plan leave in advance.

\section{Awareness on leave eligibility}

- $\quad 82 \%$ of employees have responded, they are completely aware on leave eligibility.

- $16 \%$ of employees have responsed, they are partially aware on leave eligibility.

- $2 \%$ of employees have responsed, they are not aware on leave eligibility.

\section{CONCLUSION}

On the basis of the analysis made, the following conclusions are drawn:

- Maximum number of participants have stated that they prefer to work in General shift work hour.

- Most of the employees from the pool of population samples they are satisfied with the nature of job.

- Maximum number of participants are little aware on the impact of absenteeism in daily production.

- Maximum participants takes leave on account of festival ceremonies from work.

- Maximum participants never take leave for social and political activities.

- Maximum participants take leave due to family problem or issues in their personal life.

- Maximum participants have very good relationship with their supervisors.

- Maximum participants have good relationship with their co-workers.

- Most of the participants takes leave in the middle of the month.

- Maximum participants sometimes only taking leave from work and not often.

- Maximum participants sometimes only plan their leave in advance.

- Most of the participants are completely aware on the eligibility of the leaves.

\section{RECOMMENDATION AND SUGGESTIONS}

- The management should concentrate more on motivating level 4 employees to bring down the cost. It is observed that the effect of cost is directly proportional to the absenteeism in higher levels. Since, the higher levels of employees are paid more than that of the lower level employees.

- Motivational activities like fun at work, sport activities, get together, team building activities etc will make these young employees to involve themselves and also reduce absenteeism.

- It is observed that processors level of employees are frequently absent themselves. They are free to take leave as they wish because of fewer responsibilities, therefore specific responsibilities be assigned on them.

- During religious festivals, the team mates of other religion can be requested to extend their cooperation in sharing the work of absent employees which makes the production stable.

- The management must make the work challenging for the workers in order to make them satisfied in their work. For this purpose, the individual responsibilities for employee can be assigned by variety of tasks and give rewards on the performance of the given task.

- Wages of the employees or bonus at processor level can be increased where they find no salary appraisal when compared to other levels of employees.

- Impact of absenteeism in production must be inculcated to all Level of employees to reduce the cost of the company.

- Leave encashment can be introduced to reduce the absenteeism.

\section{REFERENCES}

1. Bogeurt and Dass, http://www.benefits .org / interface/cost/absent2.htm

2. Chadwick, 1977 www.workrelationships.com/site/ire/sample 3 roi.htm

3. Conver, www.oaktraining. Com/ Absenteeism. Html $-25 \mathrm{k}$

4. Clegy 1983, http://www.chillibreeze.com/index.asp

5. Clarkke, Human Resource Management, Chicago publications Ltd.,

6. Chakrapani, Human Resource Management, Tata Mc Graw - Hill Publishing company Ltd.

7. Enid Perlin, 1977 Human Resource Management, Tata Mc Graw - Hill Publishing company Ltd

8. Froideavaux, http:/www.aiims.edu/aims/event/absenteeism - notice.html

9. Garison 1977, www.workrelationships. Com/site/ira/sample_3_roi.htm

10. Porter 1975, Absenteeism in Organisation, Anurag Jain for Excel Books.

11. Smith.F.J.1977, http://www.voicendata.com/

\section{AUTHORS PROFILE}

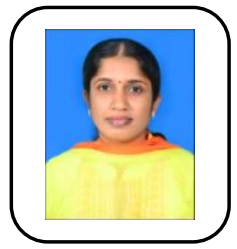

The name of First Author is "S.Sangeetha". She has completed B.Sc., (Mathamatics), MBA (HRM) and M.Phil(HRM). She has got first markin M.Phil degree.Currently the author is pursuing Full Time Ph.D in Management at Department of Adult \& Continuing Education, University of Madras. She has published research papers in reputed International Journals. She is also a life member in All India Council for Mass Education and Development. She was worked as a Training Coordinator in reputed MNC in Chennai for past 9 years. Expertise in meeting the set SLA's through Knowledge management, process management, people management, transition management and stakeholder management.The Author also has hands on research experience during MBA and M.Phil (HRM). She has got First Rank holder in MBA (HRM) in Loyola College (PULC). Received a Medal and Certificate for "School First Rank" from District Collector and won first prize for Essay competition from Chennai Mayor. She had got the "ThirukuralSelvi" award from Govt of Tamil Nadu.

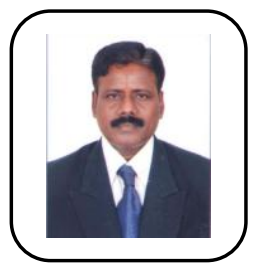

The name of Second Author is "Dr. .G. Sundharavadivel". $\mathrm{He}$ is a "Professor" at Department of Adult \& Continuing Education, University of Madras with more than 15 years of Experience in the field of Adult and Continuing Education. The author is a rank holder in MA (Andragogy), did Ph.D. in Vocational Education from the University of Madras. He did his M.L.M, MBA and M.Phil.(Entrepreneurship) from M.K. University. The author has completed M.S.W, M.Sc. (Yoga) from Annamalai University and PGDHRM from Pondicherry University. The author served as programme officer NSS from 2005 to 2010 and has presented papers in National and International seminar, Conferences and workshops .The author has also completed M.COM (Education Management).The author has received "Aasiriyar Semmal" award from Thamizhaga Institute of Educational Research and Advancement (TIERA) on teacher's day, September 5th 2019 and "Best professor" award from ESN Publications on 28th September 2019.He has published in the reputed and UGC approved journals. 